\title{
Boswellic acid sensitizes gastric cancer cells to Cisplatin-induced apoptosis via p53- mediated pathway
}

Shadia Al-Bahlani ${ }^{1 * \dagger}$, Ikram A. Burney ${ }^{2+}$, Buthaina Al-Dhahli ${ }^{1}$, Safiya Al-Kharusi ${ }^{1}$, Fakhra Al-Kharousi', Amani Al-Kalbani ${ }^{1}$ and Ikhlas Ahmed ${ }^{3}$

\begin{abstract}
Background: Cisplatin (CDDP) is an effective anticancer drug for Gastric cancer (GC) that induces apoptosis by altering pro- (p53) and anti-apoptotic (Akt and NFkB) proteins; however, chemoresistance remains a big challenge. Additional compounds with promising anticancer effects such as AKBA (Acetyl-keto-beta boswellic acid) may overcome the resistance. However, its role in CDDP-induced apoptosis in GC has not been studied. This study aimed to examine the effectiveness of AKBA on p53-mediated, CDDP-induced apoptosis in GC cells. AGS and NClN87 cells were treated with different concentrations $(0,25,50,100 \mu \mathrm{M})$ of CDDP and/or AKBA.

Methods: P53, Akt and NFkB proteins and apoptosis were assessed by Western blot and flow cytometry. The role of p53 was determined by inhibiting its function via the siRNA approach.

Results: The results revealed that CDDP and AKBA significantly increased p53 content in both cells, while Akt and NFkB were significantly decreased. Both compounds significantly induced apoptosis in a dose-dependent manner. AKBA sensitized GC cells to CDDP-induced apoptosis by altering the protein expression. P53 downregulation affected Akt and NFkB proteins with a slight increase in apoptosis induction in the combination treated groups.

Conclusions: Altogether, our findings suggest that AKBA enhances GC cell sensitivity to CDDP-induced apoptosis via the p53 pathway.
\end{abstract}

Keywords: P53, CDDP, AKBA, Apoptosis and gastric cancer

\section{Background}

Gastric cancer (GC) is the fourth most common cancer and the 3rd most common cause of cancer-related mortality worldwide $[1,2]$. Its incidence varies with geographical regions, for example, the incidence is 20 times higher in Japan, Chile and Costa Rica compared to North America and the Northern Europe [3]. GC is one of the 10 most common cancers in Oman [4]. Cisplatin

\footnotetext{
* Correspondence: bahlani@squ.edu.om

'Shadia Al-Bahlani and Ikram A. Burney contributed equally to this work. 'Department of Allied Health Sciences, College of Medicine and Health Sciences, Sultan Qaboos University, P. O. Box 35, PC 123 AlKhoud, Muscat, Oman

Full list of author information is available at the end of the article
}

(Cis-diammine dichloro platinumor; CDDP) and its derivatives remain the standard of care in the treatment of GC. CDDP causes damage to the cancer cells by exerting cytotoxic effects on DNA replication through crosslinking, eventually resulting in apoptosis [5, 6]. Although CDDP is effective initially, eventually tumors develop resistance due to an increase in DNA repair or elevated levels of glutathione, which neutralizes the reactive oxygen species formed by CDDP [7].

CDDP induces apoptosis by activating the p53mediated apoptotic pathway. Factors that activate p53 protein include internal and external stress signals [8]. In normal situations, p53 binds to $\mathrm{Mdm} 2$ protein

(c) The Author(s). 2020 Open Access This article is licensed under a Creative Commons Attribution 4.0 International License, which permits use, sharing, adaptation, distribution and reproduction in any medium or format, as long as you give appropriate credit to the original author(s) and the source, provide a link to the Creative Commons licence, and indicate if changes were made. The images or other third party material in this article are included in the article's Creative Commons licence, unless indicated otherwise in a credit line to the material. If material is not included in the article's Creative Commons licence and your intended use is not permitted by statutory regulation or exceeds the permitted use, you will need to obtain permission directly from the copyright holder. To view a copy of this licence, visit http://creativecommons.org/licenses/by/4.0/. The Creative Commons Public Domain Dedication waiver (http://creativecommons.org/publicdomain/zero/1.0/) applies to the data made available in this article, unless otherwise stated in a credit line to the data. 
preventing its function as a transcription factor, but when mutated, expression of p53 is up-regulated [9]. Other proteins are also involved in regulation of cell survival and death and adversely affect p53-mediated apoptosis such as Akt and NFkB proteins [10]. Akt is considered to be one of the most important molecular drivers inducing malignancies, including the GC. Activation of Akt results in cell proliferation and survival through activation of other substrates such as mTOR and Cyclin D. CDDP induces Akt cleavage and thus apoptosis [11, 12]. Nuclear factor kappa-light-chain-enhancer of activated B cells (Rel/NFkB) is also a transcription factor that binds to an inhibitory molecule called IKB. CDDP induces IKB degradation and hence activation of NFkB [13].

AKBA (Acetyl-keto- boswellic acid), extracted from frankincense of Boswella Sarca tree, has shown promising anticancer effects in certain types of cancer including brain, colon, prostate and pancreas [14, 15]. Previously published reports have shown that the effect was mediated by activation of several apoptosis pathways including the PI3K/Akt, the Wnt/ $\beta$-catenin, and the NFkB/ COX-2 signaling pathways [16].

Liu $J$ and his team demonstrated that AKBA can induce apoptosis in colon cancer cells; however, its role in p53-dependent-apoptosis is not studied yet [17]. In addition, the combined effect of AKBA and CDDP on GC cells and the mechanism of cytotoxicity has not been studied yet. Therefore, this study was designed to explore the role of p53 in both CDDP- and AKBA- mediated apoptosis and whether, there is a synergistic effect in overcoming the chemoresistance.

\section{Methods}

\section{Reagents and antibodies}

F-12 K Nut Mix medium, Roswell Park Memorial Institute medium (RPMI), $0.25 \%$ Trypsin-EDTA, penicillin and streptomycin and fetal bovine serum (FBS) were obtained from Gibco (Scotland, UK). CDDP $(50 \mathrm{mg} / 50 \mathrm{~mL})$ was obtained from Hospira, USA. AKBA $(10 \mathrm{mM})$ was obtained from SIGMA-ALDRICH (Saint Louis, USA). FlowCellect Annexin Red Kit was obtained from Millipore (Darmstadt, Germany). Primary antibodies of rabbit monoclonal anti -Akt, -NFkB,-GAPDH, \& -PARP and mouse monoclenal anti-p53 in addition to secondary antibodies (Gout antirabbit and -mouse IgG (HRP conjugated) were obtained from cell signaling technology (Beverly, MA, USA). P53 siRNA was also purchased from the same company. SuperSignal West Dura Extended Duration Substrate was obtained from Pierce (Rockford, IL, USA).

\section{Cell culture}

Human gastric cancer cell lines NCI-N87 and AGS were purchased from ATCC (Virginia, USA) and have been recently reported by Liu et al. [18] Both cell lines were cultured at $37{ }^{\circ} \mathrm{C}$ in a humidified $5 \%$ carbon dioxide atmosphere. Seeding density for AGS was 8000 cells $/ \mathrm{mm}$ while for NCI-N87 was 15000 cells/mm in an appropriate 24-well plate or 6-well plate. RPMI-1640 was used as media for NCI-N87, and was supplemented with $10 \%$ FBS, $1 \%$ penicillin and $1 \%$ streptomycin, while F-12 K media (Gibco, UK) was used for AGS cells with the same supplements. Both types of cells were treated with different concentrations of $\operatorname{CDDP}(0,50$ and $100 \mu \mathrm{M})$ and/or AKBA $(0,25,50$, and $100 \mu \mathrm{M})$. These concentrations were used previously in similar studies on gastric, colon and pancreas cell lines [17-22]. Finally, they were harvested after $24 \mathrm{~h}$ for further analysis.

\section{P53 siRNA transfection}

In NCI-N87 cell line, p53 protein expression was downregulated using p53-siRNA, as described earlier [22]. Briefly, cells were treated for $24 \mathrm{~h}$ with $150 \mathrm{nM}$ of p53 siRNA, followed by CDDP and/or AKBA treatment for another $24 \mathrm{~h}$. Cells were then harvested for further analysis.

\section{Protein extraction and Western blot analysis}

Protein extraction and Western Blot were performed as described previously [22]. Briefly, AGS and NCI-N87 cell lines were harvested and treated with lysis buffer (50 mM Hepes, $150 \mathrm{mM} \mathrm{NaCl}, 1 \mathrm{mM}$ EGTA, $10 \mathrm{mM}$ Sodium Pyrophosphate (Nappi), $1.5 \mathrm{mM} \mathrm{MgCl}_{2}, 100 \mathrm{mM}$ NaF, $10 \%$ Glycerol, $1 \%$ Triton X-100) to extract the proteins. Samples were then centrifuged to purify the proteins, and BCA protein assay kit was used to quantify the amount of proteins (BioVision, California, USA).

Western blot was done following BioRad protocol. Fifty microgram of protein samples were loaded and ran on $10 \%$ SDS-PAGE gel. Proteins were transferred to a Polyvinylidene difluoride PVDF membrane (Thermo Scientific, Rockford, IL, USA), which was blocked using $5 \%$ milk for $30 \mathrm{~min}$. Next, primary antibody (11000) in 5\% milk to the membrane was added, and incubated for an hour at room temperature. Then the membrane was washed 3 times with $1 x$ TBST to remove any non-specific binding. Secondary IgG (15000) was added to the membrane and incubated for an hour at room temperature; the membrane was washed 3 times again with $1 \mathrm{x}$ TBST. Protein was then detected using West Dura kit (Pierce, Rockford, IL, USA). The solution was prepared by mixing (1) of the stable peroxide buffer and Luminal/ Enhancer solution. The membrane was incubated for $3 \mathrm{~min}$ at room temperature. Eventually G-Box machine using GeneSys software was used to detect the bands.

\section{Apoptosis analysis}

FlowCellect Annexin Red Kit was used to detect vaible and apoptotic cancer cells. First, cell samples were 
prepared in 1X Assay Buffer HSC; $100 \mu \mathrm{L}$ of each cell sample was pipetted into an appropriate well and $100 \mu \mathrm{L}$ Annexin Red Working solution was added. Cells were incubated at $37^{\circ} \mathrm{C}$ for $15 \mathrm{~min}$. Following incubation, each well was washed once with $200 \mu \mathrm{L} 1 \mathrm{X}$ Assay Buffer HSC. Afterwards the cell pellet was resuspended in $195 \mu \mathrm{L} 1 \mathrm{X}$ Assay Buffer HSC and $5 \mu \mathrm{L}$ of 7 -AAD were added per well. Then, wells were incubated at room temperature for $5 \mathrm{~min}$ in the dark. Finally, the analysis was done on dual laser flow cytometer.

\section{Statistical analysis}

All data are expressed as mean \pm standard error (SE) of at least three independent replicates. They were analyzed by the single-factor analysis of variance (One-way ANOVA) using the SPSS program ${ }^{\circ}$, version 23. Significant differences between measurements are indicated at ***P$P<0.001, " * P<0.05$ and ${ }^{*} P<0.01$. Bands of Western Blot were quantified using ImageJ Software.

\section{Results}

CDDP had differential effect on proteins expression and induced apoptosis in GC cells

We first aimed to measure the effect of CDDP on p53, Akt and NFkB proteins expression and apoptosis induction in GC cells. Fig. 1a reveals a significant increase in the expression of p53 in NCI-N87 and AGS cells while Akt and NFkB expression is significantly decreased. AGS cells show minimal expression of only p53 protein in the control group. PARP cleavage was a good indicator of the cells response to CDDP treatment. Total-PARP expression decreased in parallel with an increase of it's cleaved form, indicating its activity in facilitating apoptosis. GAPDH was used as a loading control to normalize to total protein content the expression of proteins of interest. Figure $1 b$ \& $2 c$ show that CDDP significantly induced apoptosis in a concentration-dependent manner in both cell lines; AGS cells responded more compared to the NCI-N87 cells.

\section{AKBA exhibited similar effect as CDDP on proteins expression and apoptosis in GC cells except for p53} Although some studies have shown that AKBA may induce apoptosis in certain cancer types, none examined its effect in gastric cancers and on the p53-depedent pathway. Therefore, after measuring the effect of CDDP, we examined if AKBA will also exhibit similar effect on the protein expression and apoptosis induction in the studied cells. Unlike CDDP, AKBA had no effect on p53 protein in AGS cells, but increased its expression in NCI-N87 cells at a concentration of 25 and $50 \mu \mathrm{M}$. On the other hand, it had an effect similar to CDDP in reducing Akt and NFkB proteins expression in both cell lines
(Fig. 2a). AKBA had a similar effect in inducing apoptosis in both cell lines as indicated in Fig. $2 \mathrm{~b}$ and c.

A dose of $100 \mu \mathrm{M}$ of AKBA was found to be toxic as indicated by the loss of protein expression and high percentage of apoptosis (71.9 and $85.4 \%$ in AGS and NCIN87 cell lines respectively), suggesting its behavior as a potent cytotoxic compound.

\section{AKBA sensitized GC cells to CDDP-induced apoptosis via altering proteins expression}

We investigated the extent to which the combination of AKBA and CDDP were associated with modification of apoptosis and protein expression of p53, Akt, and NFkB in GC cells. Based on Fig. $1 \mathrm{~b}$ and 2b, optimal concentration of each compound and for each cell lines were selected; NCI-N87 cells were treated with $50 \mu \mathrm{M}$ of CDDP and $25 \mu \mathrm{M}$ of AKBA, while AGS cells were treated with $25 \mu \mathrm{M}$ each of CDDP and AKBA. The optimum concentrations were selected based on our findings from Figs. 1 and 2 in which these concentrations showed significant difference compared to the controlled group. In addition, Liu et al and his team supported our selection when they found that $\mathrm{IC}_{50}$ of CDDP for NCI-N87 cell line is higher than AGS cells [18], hence NCI-N87 cells were treated with $50 \mu \mathrm{M}$ and AGS $25 \mu \mathrm{M}$. The combined treatment of both CDDP and AKBA showed more effect on the expression of three proteins compared to the single treatment in both cells as shown in Fig. 3a. However, the same was not true for apoptosis induction, in which combining CDDP and AKBA had no significant increase compared to the single treatment, yet it was significant compared to the control group for AGS and NCI-N87 cells. Altogether, this suggested that both compounds have additive effect that work on similar apoptotic pathways.

\section{P53-dependent pathway mediated CDDP- and AKBA- induced apoptosis in GC cells}

Although we showed that both CDDP and AKBA influence p53 protein expression, its role in regulating these cells sensitivity to both compounds had not been studied yet. Therefore, to assess such a specific role of CDDP- and AKBA-induced apoptosis, p53 protein was down-regulated using siRNA in NCI-N87 cells only, since it was not detected in AGS cells at the basal level. Figure 4a shows consistent effect of both compounds on the expression of all three proteins; as well on apoptosis induction in both cells. P53 siRNA was successful in reducing the increase in p53 expression post-treatment up to approximately $70 \%$. The expression of Akt and NFkB proteins was further reduced by the combined treatment when p53 protein was down-regulated, suggesting their role as downstream effectors in the p53 pathway. Although, 


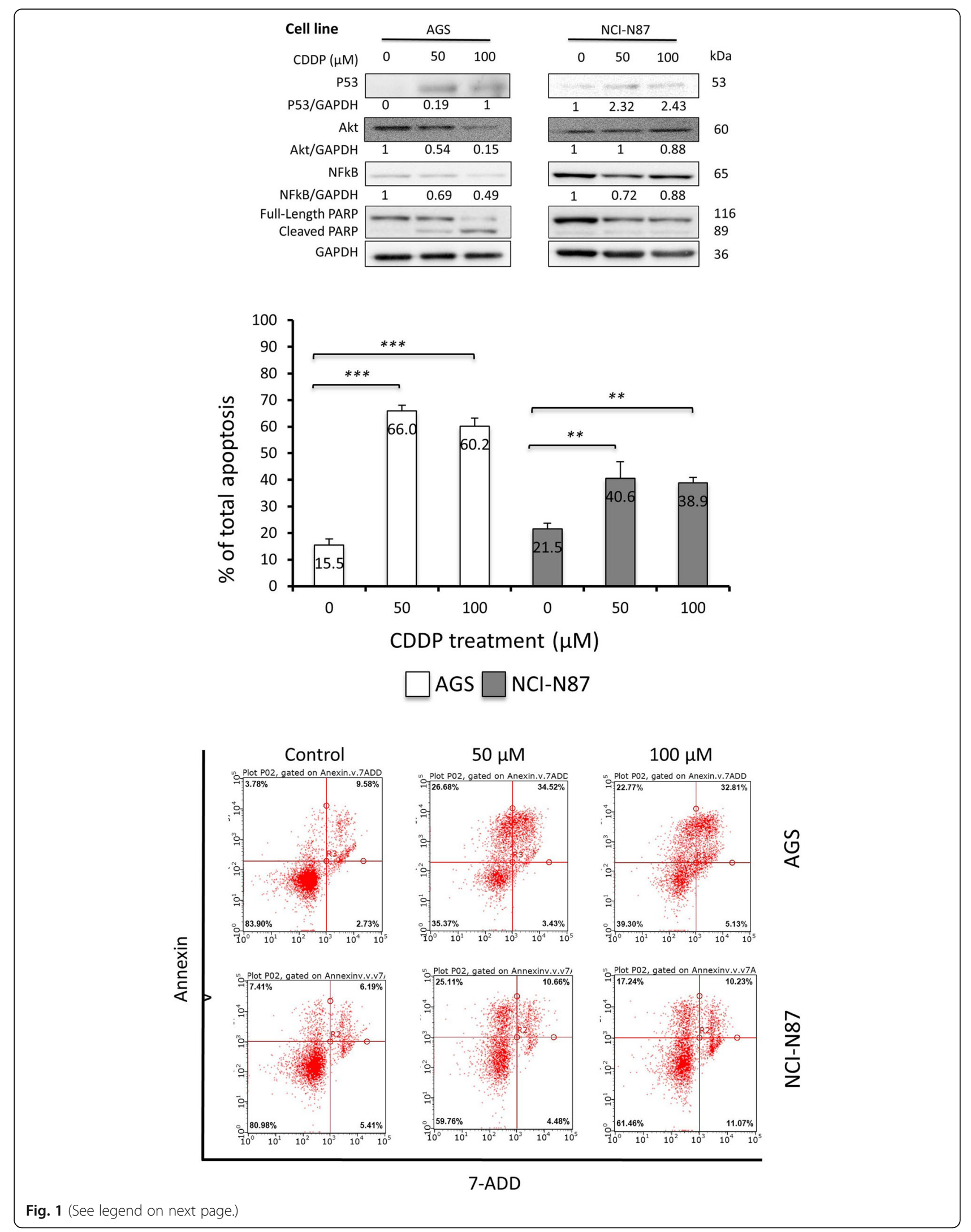


(See figure on previous page.)

Fig. 1 CDDP had differential effect on proteins expression and induced apoptosis in GC cells. a Western blot shows the effect of CDDP on protein expression in AGS and NCl - N87 cell lines. The expression of tumor suppressor protein 53 increased with CDDP concentration, whilst Akt and NFKB expressions reduced, notice the cleaved PARP which indicates apoptosis $\mathbf{b}$ Graphical presentation of apoptosis percentages in AGS and $\mathrm{NCl}-\mathrm{N} 87$ cell lines treated with different concentrations of CDDP showing significant increase in apoptosis in comparison to control concentration $\left({ }^{*} P<0.05,{ }^{*} P<0.01,{ }^{* *} P<0.001\right)$. The response of AGS cells is more evident than NCl-N87. c Flow cytometry graphs showing the effect of different doses of CDDP on AGS and NCI-N87 cells, each graph shows alive cells, early and late apoptotic cells, and dead cells

apoptosis induction showed a slight increase in these cells, there was no significant difference between the treated groups, with and without p53 down regulation, suggesting that $\mathrm{p} 53$ pathway might contribute to both CDDP-and AKBA-dependent apoptosis at the upstream mediators.

\section{Discussion}

Understanding the mechanisim of action of CDDP and AKBA in apoptosis induction in GC cells is a crucial step to suggest successful treatment strategy. This study demonstrated an important role of the p53 pathway in the regulation of GC sensitivity to CDDP- and AKBA-dependent apoptosis. It also provides evidence that a defect in such pathway might result in resistance to CDDP and/or AKBA treatment. As many drugs that affect multiple pathways, boswellic acid acetate was also found to induce apoptosis via p53-independent pathway as Xia L et al and his team showed in myeloid leukemia cell [23]. They demonstrated that the levels of apoptosisrelated proteins $\mathrm{Bcl}-2, \mathrm{Bax}$, and $\mathrm{Bcl}-\mathrm{XL}$ were not modulated by boswellic acid acetate, however; it induced Bid cleavage and decreased mitochondrial membrane potential without production of hydrogen peroxide. By using general caspase inhibitor (ZVAD-FMK) and a specific caspase- 8 inhibitor II (ZIETD-FMK), boswellic acid acetate-induced apoptosis was blocked, suggesting that such mechanism was through activation of caspase- 8 and not p53. Such variation in boswellic acid acetate action might be due to the differences in genetic background of both cancer types as well as the activities of these tested proteins.

Here, we have shown that both CDDP and AKBA significantly increased the expression of p53 in NCIN87 and AGS cells while Akt and NFkB expressions were significantly decreased. The two compounds also induced significant apoptosis in a dose-dependent manner in both cell lines in which AGS cells responded more effectively compared to the NCI-N87 cells. Furthermore, AKBA sensitized GC cells to CDDP-induced apoptosis via altering the protein expression. Gene manipulation of p53 expression by siRNA, and thus protein reduction, affected expression of Akt and NFkB proteins and thus increased apoptosis in the group treated by a combination of CDDP and AKBA.

Several studies have confirmed the efficacy of CDDP as a potent anticancer agent for GC [18, 24, 25]. They showed that CDDP significantly increased apoptosis in a concentration-dependent manner, in which AGS cells was more sensitive while NCI-N87 cells were more resistant to CDDP, consistent with our findings.. The NCI-N87 cells are HER-2 positive, and a previous study suggested that this may make cells more resistant to CDDP [26].

Studies have demonstrated that CDDP induces upregulation of p53 in GC cells, a finding consistent with our current study [27, 28]. On the other hand, CDDP reduced phosphorylation level of Akt, and hence its expression in GC cells [29], supporting our results where CDDP reduced Akt expression in the tested cells.

Whereas very few studies tested the efficacy of AKBA in cancer cells. Liu, et al. showed that AKBA at dose of $100 \mu \mathrm{M}$ triggers apoptosis via a caspase-8dependent pathway in colon cancer HT-29 cell line [17]. Another study showed that AKBA can inactivate STAT3 pathway, a pathway that participates in the activation of Akt gene expression [14]. Altogether, suggesting that AKBA can act on different molecular mechanisms and pathways accountable for inducing cell apoptosis in different cancer cell types. Examples of these targets at the cellular molecular level includes but not restricted to kinases, growth factors, transcription factors, enzymes and receptors [14]. Takada et al. detected that AKBA affects NFkB expression in lung adenocarcinoma H1299 cells and human T-cell leukemia Jurkat cells [30]. Moreover, the cytotoxic and antitumor effects are mainly due to induction of apoptosis through caspase activation, increased Bax expression, NF- $\mathrm{kB}$ downregulation and induction of poly (ADP)-ribosepolymerase (PARP) cleavage [30].

Although some studies have reported that AKBA appear to be a promising anticancer drug independently, studies in combination with clinically used anticancer drugs may suggest even more promising anti-cancer activity [16]. For example, Abdelaziz, 


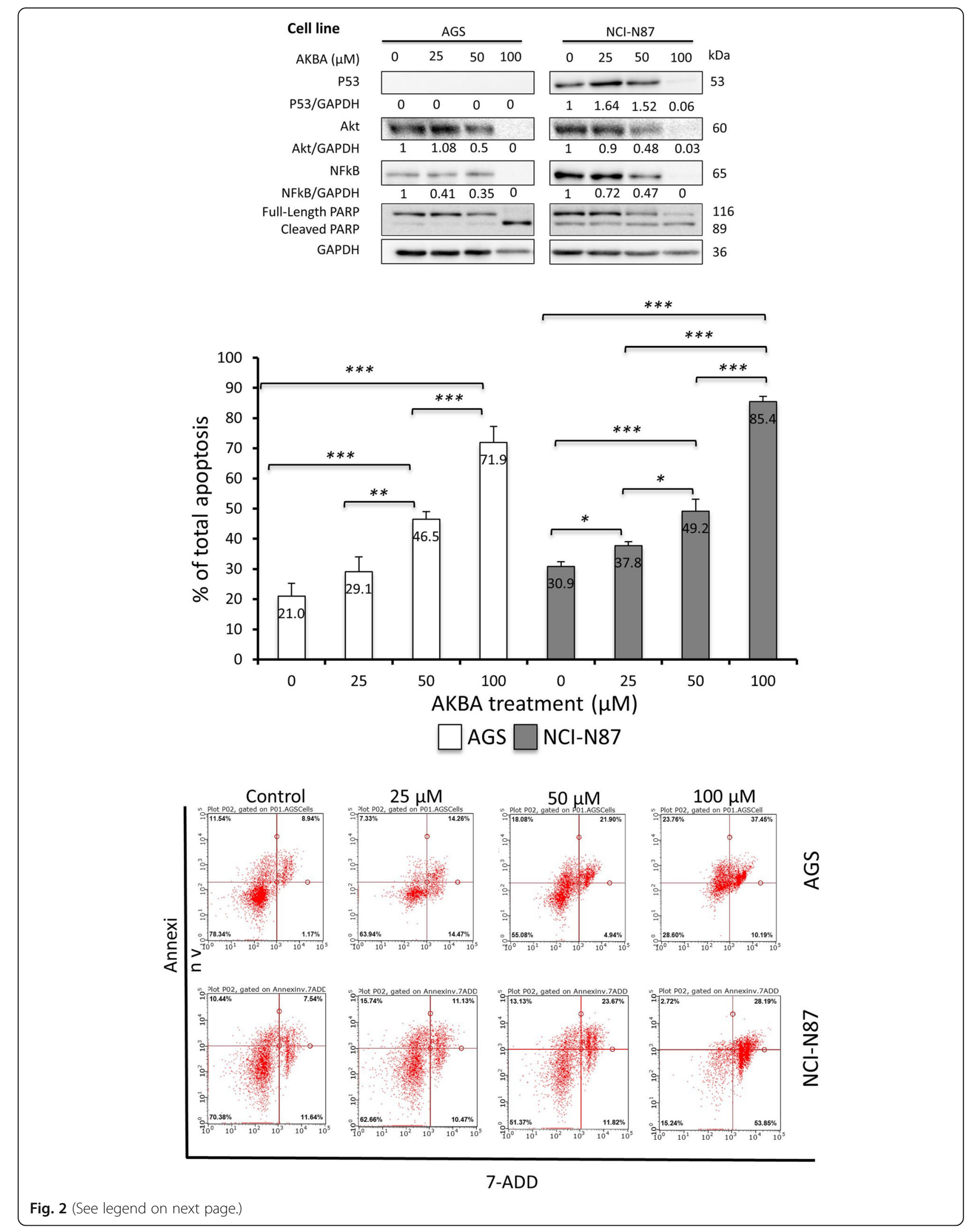


(See figure on previous page.)

Fig. 2 AKBA exhibited similar effect as CDDP on proteins expression and apoptosis in GC cells except for p53. a Western blot shows the effect of AKBA on protein expression in AGS and NCl - N87 cell lines. The expression followed a similar pattern to the cells treated with CDDP $\mathbf{b}$ Graphical presentation of apoptosis percentage in AGS and NCI-N87 cell lines treated with different concentrations of AKBA showing significant increase in apoptosis in comparison to control concentration $\left({ }^{*} P<0.05,{ }^{*} P<0.01,{ }^{* *} P<0.001\right)$. The concentration of $100 \mu \mathrm{M}$ was found to be highly toxic and the apoptosis percentages reached 71.9 and $85.4 \%$ in AGS and NCI-N87 cell lines respectively. c Flow cytometry graphs showing the effect of different doses of AKBA on AGS and NCI-N87 cells. Each graph shows alive cells, early and late apoptotic cells, and dead cells

et al. reported a potential anti-angiogenic effect of a combination of AKBA and CDDP against chemicallyinduced colon cancer $(C C)$ in mice [21]. They transplanted $\mathrm{CC}$ cells in seventy healthy male albino mice and then treated them with AKBA, CDDP or both.
Significant decrease in tumor proliferation index and serum markers was detected in the combination therapy arm rather than the mono-therapy, suggesting that AKBA augments the antitumor effect of CDDP.
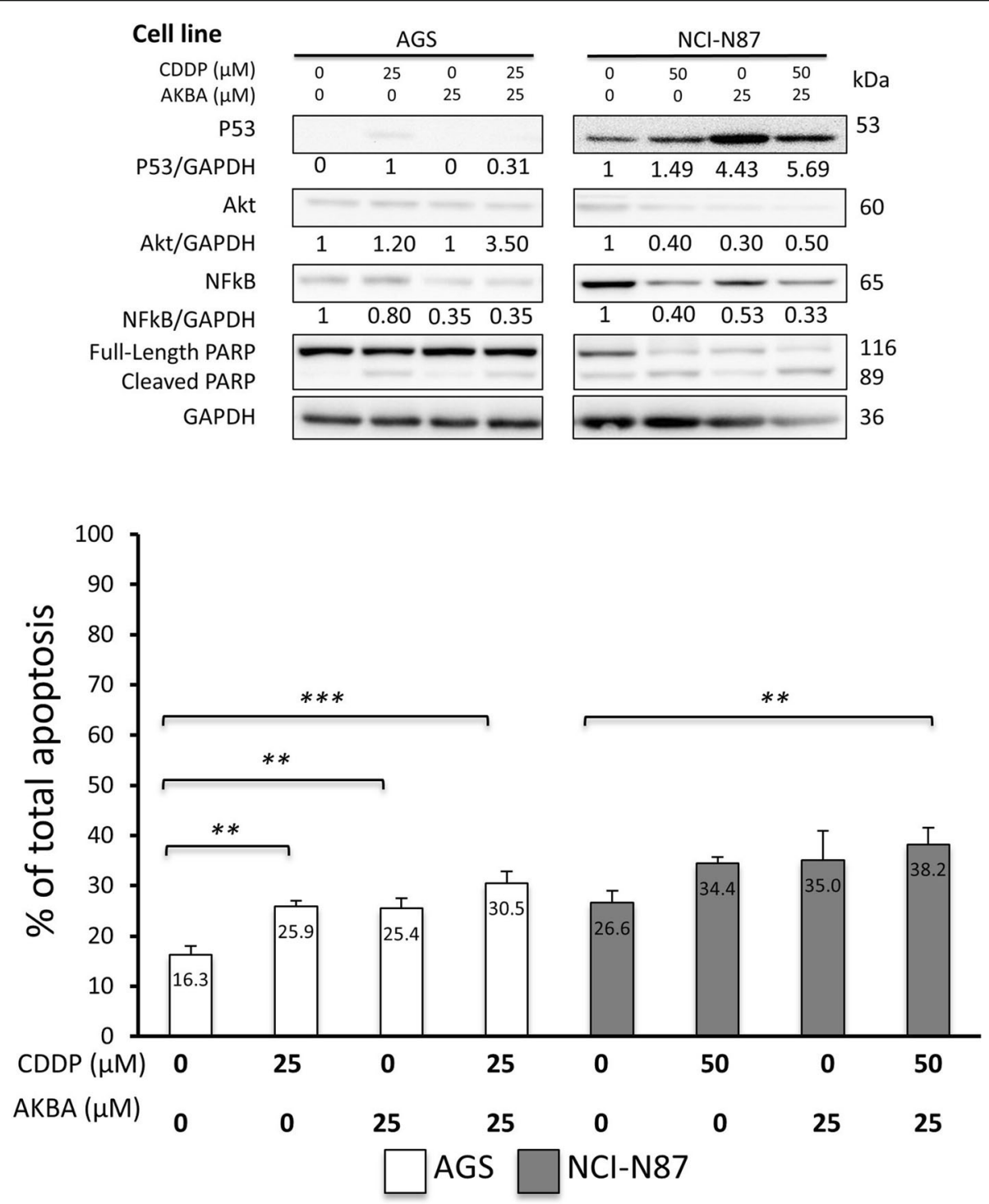

Fig. 3 AKBA sensitized GC cells to CDDP-induced apoptosis via altering proteins expression. a Western blot shows the effect of combined CDDP and AKBA on protein expression in AGS and NCl - N87 cell lines. $\mathbf{b}$ Graphical presentation of apoptosis percentage in AGS and NCI-N87 cell lines treated with different concentrations of CDDP and AKBA showing significant increase in apoptosis in comparison to control concentration $(* P<$ $\left.0.05,{ }^{*} P<0.01,{ }^{* *} P<0.001\right)$ 


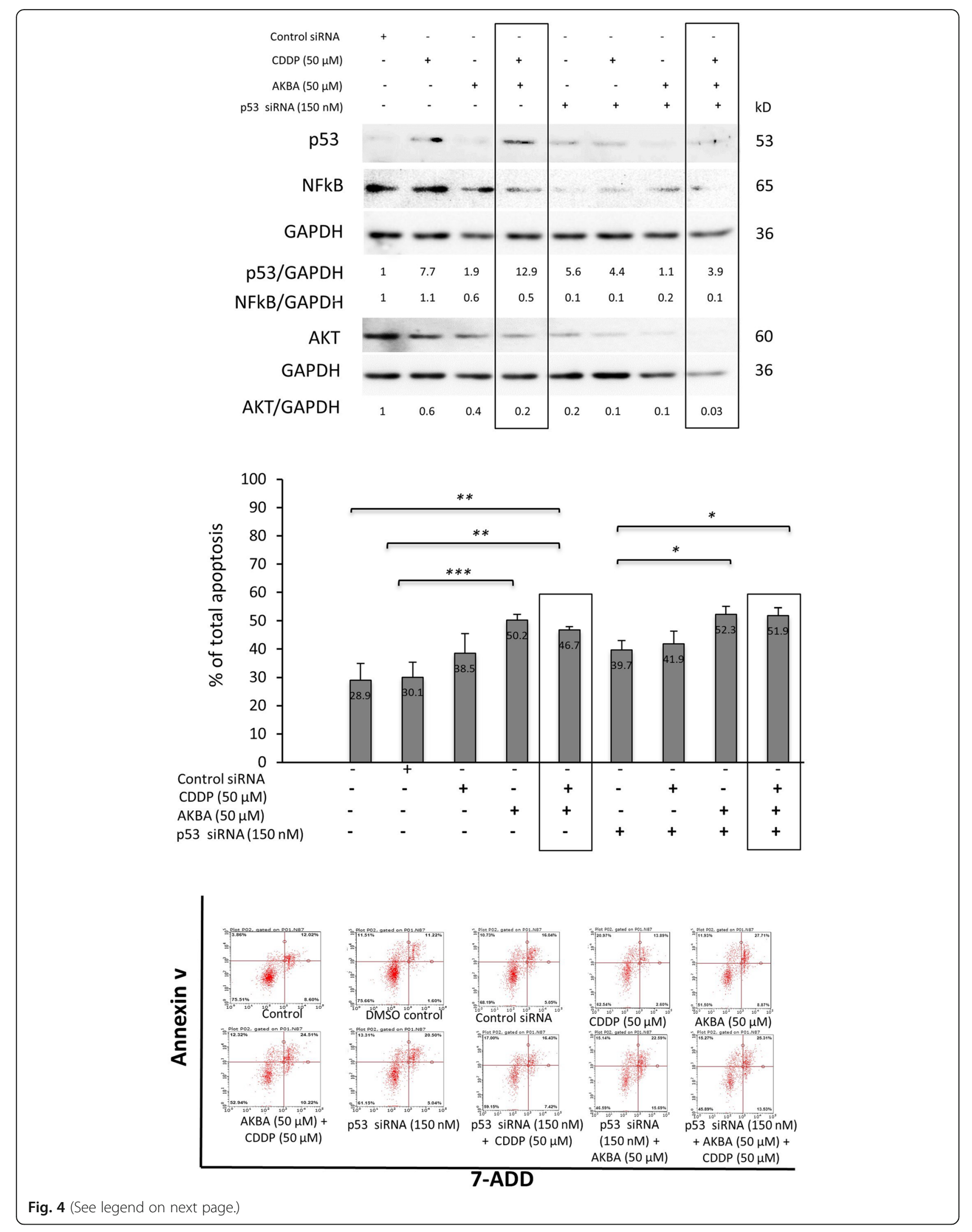


(See figure on previous page.)

Fig. 4 P53-dependent pathway mediated CDDP- and AKBA-induced apoptosis in GC a Western blot shows the effect of siRNA, CDDP and AKBA on protein expression in $\mathrm{NCl}-\mathrm{N} 87$ cell line. P53 siRNA was successful in reducing the increase in p53 expression post treatment of CDDP and AKBA up to approximately 70\%. The expression of Akt and NFkB proteins was further reduced in the combined treatment when p53 protein was down-regulated $\mathbf{b}$ Graphical presentation of apoptosis percentage in NCI-N87 cell line treated with different treatments showing varying degrees in apoptosis in comparison to control concentration. Apoptosis induction showed a slight trend of increase with no significant difference between treated groups with and without p53 down regulation. ( ${ }^{*} P<0.05$, ${ }^{*} P<0.01$, $\left.{ }^{*}{ }^{*} P<0.001\right)$. (c) Flow cytometry graphs showing the effect of different treatments on NCI-N87 cells. Each graph shows alive cells, early and late apoptotic cells, and dead cells

\section{Conclusion}

In conclusion, to the best of our knowledge, we are the first to show the effectiveness of AKBA in sensitizing gastric cancer cells to CDDP-induced apoptosis via p53dependent pathway in GC cells. Understanding the molecular mechanisms of CDDP resistance and how to effectively overcome the resistance will provide insight in overcoming chemoresistance. One method of overcoming the ressitance is to use an adjuvant compound like AKBA, which itself has promising anticancer properties.

\section{Abbreviations}

AKBA: Acetyl-11-Keto-Beta-Boswellic Acid; Bcl-2: B-Cell Lymphoma 2; CDDP: Cis-Diammine Dichloro Platinum; CO2: Carbon Dioxide; DNA: Deoxyribonucleic acid; FASL: Fatty Acid Synthase Ligand; GC: Gastric cancer; HER2: Human Epidermal Growth Factor Receptor 2; NFkB: Nuclear factor kappa-light-chain-enhancer of activated B cells; siRNA: small interference RNA; TNF: Tumor Necrosis Factor

\section{Acknowledgements}

Not Applicable.

\section{Authors' contributions}

SB: concept, design and supervision of the study, literature search, critical revision of the manuscript. IB: concept and design of the study, literature search, critical revision of the manuscript. SK: manuscript preparation, laboratory investigations, data collection, analysis, and interpretation. BD, FK \& AK: laboratory investigations, data collection, analysis, and interpretation. IA: GC cell line provider and final revision of the manuscript. All authors have read and approved the manuscript.

\section{Funding}

This work was supported by a grant from College of Medicine and Health Sciences, Sultan Qaboos University (Grant No. IG/MED/ALIE/16/01).

\section{Availability of data and materials}

Data sharing is not applicable to this article as no datasets were generated or analysed during the current study.

\section{Ethics approval and consent to participate}

Not Applicable.

\section{Consent for publication}

Not Applicable.

\section{Competing interests}

The authors declare no competing Interests.

\section{Author details}

${ }^{1}$ Department of Allied Health Sciences, College of Medicine and Health Sciences, Sultan Qaboos University, P. O. Box 35, PC 123 AlKhoud, Muscat, Oman. 'Department of Medicine, College of Medicine and Health Sciences, Sultan Qaboos University, Muscat, Oman. ${ }^{3}$ Department of Pharmacology and Clinical Pharmacy, College of Medicine and Health Sciences, Sultan Qaboos University, Muscat, Oman.
Received: 12 June 2020 Accepted: 25 August 2020

Published online: 01 September 2020

\section{References}

1. Bray F, Ferlay J, Soerjomataram I, Siegel R, Torre L, Jemal A. Global cancer statistics 2018: GLOBOCAN estimates of incidence and mortality worldwide for 36 cancers in 185 countries. CA Cancer J Clin. 2018;68(6):394-424. https://doi.org/10.3322/caac.21492.

2. WHO. Cancer. Who.int. http://www.who.int/mediacentre/factsheets/fs297/ en/. Published 2017.

3. Abbas A, Aster J, Kumar V, Perkins J. Robbins Basic Pathology. 9th ed: Elsevier Saunders; 2013. p. 570-3.

4. Al-Lawati N, Al-Bahrani B, Al-Raisi S, Al-Lawati J. Twenty-year trends of Cancer incidence in Omanis, 1996-2015. Oman Med J. 2019:34(4):361-87.

5. Clark M, Finkel R. Lippincott's Illustrated Reviews: Pharmacology. 5th ed. Baltimore: Lippincott Williams \& Wilkins; 2012. p. 507-8. IS THERE A DIFFER ENT WAY TO REFER TO A BOOK CHAPTER ?

6. Dasari S, Bernard TP. Cisplatin in cancer therapy: molecular mechanisms of action. Eur J Pharmacol. 2014;740:364-78. https://doi.org/10.1016/j.ejphar. 2014.07.025.

7. Shen D, Pouliot L, Hall M, Gottesman M. Cisplatin resistance: a cellular selfdefense mechanism resulting from multiple epigenetic and genetic changes. Pharmacol Rev. 2012:64(3):706-21. https://doi.org/10.1124/pr.111. 005637

8. Haupt S. Apoptosis - the p53 network. J Cell Sci. 2003;116(20):4077-85. https://doi.org/10.1242/jcs.00739.

9. Lane D. p53 from pathway to therapy. Carcinogenesis. 2004;25(7):1077-81. https://doi.org/10.1093/carcin/bgh186.

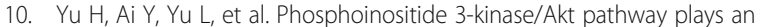
important role in chemoresistance of gastric cancer cells against etoposide and doxorubicin induced cell death. Int J Cancer. 2007;122(2):433-43. https://doi.org/10.1002/ijc.23049.

11. Muise-Helmericks R, Grimes H, Bellacosa A, Malstrom S, Tsichlis P, Rosen N. Cyclin D. Expression is controlled post-transcriptionally via a phosphatidylinositol 3-kinase/Akt-dependent pathway. J Biol Chem 1998; 273(45):29864-29872. doi:https://doi.org/10.1074/jbc.273.45.29864.

12. Gagnon V, Van Themsche C, Turner S, Leblanc V, Asselin E. Akt and XIAP regulate the sensitivity of human uterine cancer cells to cisplatin, doxorubicin and taxol. Apoptosis. 2007;13(2):259-71. https://doi.org/10.1007/ s10495-007-0165-6.

13. Gilmore T. Introduction to NF-kB: players, pathways, perspectives. Oncogene. 2006;25(51):6680-4. https://doi.org/10.1038/sj.onc.1209954.

14. Roy N, Deka A, Bordoloi D, et al. The potential role of boswellic acids in cancer prevention and treatment. Cancer Lett. 2016:377(1):74-86. https:// doi.org/10.1016/j.canlet.2016.04.017.

15. Ni X, Suhail M, Yang Q, et al. Frankincense essential oil prepared from hydrodistillation of Boswellia sacra gum resins induces human pancreatic cancer cell death in cultures and in a xenograft murine model. BMC Complement Altern Med. 2012;12(1). https://doi.org/10.1186/1472-6882-12253.

16. Khan M, Ali R, Parveen R, Najmi A, Ahmad S. Pharmacological evidences for cytotoxic and antitumor properties of Boswellic acids from Boswellia serrata. J Ethnopharmacol. 2016;191:315-23. https://doi.org/10.1016/j.jep.2016.06. 053.

17. Liu J. Boswellic acids trigger apoptosis via a pathway dependent on caspase-8 activation but independent on Fas/Fas ligand interaction in colon cancer HT-29 cells. Carcinogenesis. 2002;23(12):2087-93. https://doi.org/10. 1093/carcin/23.12.2087. 
18. Liu Y, Ling Y, Qi Q, et al. Trastuzumab increases the sensitivity of HER2amplified human gastric cancer cells to oxaliplatin and cisplatin by affecting the expression of telomere-associated proteins. Oncol Lett. 2014;9(2):9991005. https://doi.org/10.3892/ol.2014.2793.

19. Takahashi M, Sung B, Shen Y, Hur K, Link A, Boland CR, et al. Boswellic acid exerts antitumor effects in colorectal cancer cells by modulating expression of the let-7 and miR-200 microRNA family. Carcinogenesis. 2012;33:2441-9.

20. Park B, Prasad S, Yadav V, Sung B, Aggarwal BB. Boswellic acid suppresses growth and metastasis of human pancreatic tumors in an orthotopic nude mouse model through modulation of multiple targets. PLoS One. 2011;6:e26943.

21. Abdelaziz EZ, AMS H, Badawy A, Bayomy NA, Rabat AE, Fawzy MS. Potential Anti-angiogenic effect of a combination of boswellic acids and cisplatin against chemically-induced colon cancer in mice. J Chem Biol Therapeutics. 2016;01(02). https://doi.org/10.4172/2572-0406.1000111.

22. Al-Bahlani S, Al-Lawati H, Al-Adawi M, Al-Abri N, Al-Dhahli B, Al-Adawi K. Fatty acid synthase regulates the chemosensitivity of breast cancer cells to cisplatin-induced apoptosis. Apoptosis. 2017;22(6):865-76. https://doi.org/10. 1007/s10495-017-1366-2.

23. Xia L, Chen D, Han R, Fang Q, Waxman S, Jing Y. Boswellic acid acetate induces apoptosis through caspase-mediated pathways in myeloid leukemia cells. Mol Cancer Ther. 2005;4(3):381-8. https://doi.org/10.1158/ 1535-7163.MCT-03-0266.

24. Saito M, Kiyozaki H, Takata O, Suzuki K, Rikiyama T. Treatment of stage IV gastric cancer with induction chemotherapy using $\mathrm{S}^{-1}$ and cisplatin followed by curative resection in selected patients. World J Surg Oncol. 2014;12(1):406. https://doi.org/10.1186/1477-7819-12-406.

25. Mita K, Ito H, Takahashi K, et al. Adjuvant Chemotherapy with $\mathrm{S}^{-1}$ plus Cisplatin for Patients with Stage III Gastric Cancer After Curative Resection. Anticancer Res. 2017;37(3):1329-34. https://doi.org/10.21873/anticanres.11451.

26. Ito K, Mitsunaga M, Arihiro $\mathrm{S}$, et al. Molecular targeted photoimmunotherapy for HER2-positive human gastric cancer in combination with chemotherapy results in improved treatment outcomes through different cytotoxic mechanisms. BMC Cancer. 2016;16(1). https:// doi.org/10.1186/s12885-016-2072-0.

27. Satomi D, Takiguchi N, Koda K, et al. Apoptosis and apoptosis-associated gene products related to the response to neoadjuvant chemotherapy for gastric cancer. Int J Oncol. 2002:20:1167-71. https://doi.org/10.3892/ijo.20.6.1167.

28. Matsuhashi N, Saio M, Matsuo A, Sugiyama Y, Saji S. Expression of p53 protein as a predictor of the response to 5 -fluorouracil and cisplatin chemotherapy in human gastrointestinal cancer cell lines evaluated with apoptosis by use of thin layer collagen gel. Int J Oncol. 2004. https://doi. org/10.3892/ijo.24.4.807.

29. Bao A, Li Y, Tong Y, Zheng H, Wu W, Wei C. 1,25-Dihydroxyvitamin D3 and cisplatin synergistically induce apoptosis and cell cycle arrest in gastric cancer cells. Int J Mol Med. 2014;33(5):1177-84. https://doi.org/10.3892/ ijmm.2014.1664

30. Takada Y, Mukhopadhyay A, Kundu G, Mahabeleshwar G, Singh S, Aggarwal B. Hydrogen peroxide activates NF-kB through tyrosine phosphorylation of IKBa and serine phosphorylation of p65. J Biol Chem. 2003;278(26):2423341. https://doi.org/10.1074/jbc.m212389200.

\section{Publisher's Note}

Springer Nature remains neutral with regard to jurisdictional claims in published maps and institutional affiliations.

Ready to submit your research? Choose BMC and benefit from:
- fast, convenient online submission
- thorough peer review by experienced researchers in your field
- rapid publication on acceptance
- support for research data, including large and complex data types
- gold Open Access which fosters wider collaboration and increased citations
- maximum visibility for your research: over 100M website views per year
At BMC, research is always in progress.
Learn more biomedcentral.com/submissions

